\title{
Being children: children's voices on childhood
}

Claire Cassidy*, Sarah-Jane Conrad, Marie-France Daniel, Maria Figueroia-Rego, Walter Kohan, Karin Murris, Xiaoling Wu, Tsena Zhelyazkova

*Corresponding author

\begin{abstract}
Situated in the context of the children's rights, this article reports on a study involving children from eleven countries and five continents in philosophical discussions about concepts of child and childhood. Here we focus on seven of those countries. In a previous study, two of the authors explored in what kind of society children would like to live. The present study directly addresses one of the issues arising from that study: to investigate what children think childhood is and their place in society. The study raises issues around children's participation related to their conceptions of child and childhood.
\end{abstract}

Keywords: childhood; child; rights; society; philosophical inquiry

This article describes the initial findings of a unique pan-continental project where children from eleven countries were encouraged to consider the philosophical concept of "child". This article explores responses from seven of those countries: Brazil; Bulgaria; Canada; China; Portugal; Scotland and Switzerland. The present project grew from a previous one that invited children in Switzerland and Scotland to reflect on their notion of the 'good life' 
by asking them What kind of society do you want to live in? What was of note, ironically, in that study (Conrad et al, 2015) was the place the children afforded themselves in society. It was evident that the children across the age range, and in both countries, did not see themselves, or other children, as decision-makers or as empowered people in society. It is to this that the present study addresses itself by seeking to understand children's thinking on the concepts of child and childhood. In so doing, there will be implications related to how children are positioned - or position themselves - in society, and this will, in turn, raise issues around children's status, rights, voices and participation. This article will focus on some of the initial findings with the first groups of children aged between four and ten years-old. However provisional these findings may be, they clearly corroborate the view of children as excluded from a society in which they cannot participate.

\section{Experiencing childhood: A thought experiment}

If you were given the opportunity to take a pill that would turn you into an adult in an instant, would you take it? If so, why would you take it? If not, why not? The children in this study were invited to reflect on this question, originating from a thought experiment developed by Samantha Brennan (2014). The children's responses to the question afford insights into how they conceive of childhood, whether they see it as having an intrinsic or merely instrumental value and what goods they consider as being indispensable for childhood (Brennan, 2014; Gheaus, 2015).

Alanen (2012) is correct when she says that 'childhood and 'the child' are... complex phenomena' (p.419). Indeed, the area of what has become known as Childhood Studies has grown in the last thirty years or so. This is not to suggest that the study of children and 
childhood is new. Rousseau, for instance, writing in the eighteenth century, was concerned that 'We know nothing of childhood' (1948). Indeed, centuries before this, the Stoics studied children and developed what we might nowadays call developmental psychology (see Turner \& Matthews (eds.), 1998). Despite there being several studies where children talk about their lives and their childhood, peculiarly very little is known about the philosophical way in which children themselves conceive of childhood and the status they attribute to being a child within society. The present study addresses this issue by giving voice to the children. It allows the concept of child and childhood to be explored from within, i.e. from the children's perspective and to consider their philosophical reasoning around eventual distinctions and characterising features of the two concepts. The responses provided by the children raise issues around their status and how they are positioned - or better: position themselves - in society. The significance of seeking children's views on childhood and their notion of child is informative in determining the place children have and should have - in society and how participation and voice might best be facilitated in accordance with the United Nations Convention on the Rights of the Child (UNCRC) (United Nations, 1989). The study presented is thus situated in a rights-based context. The objectives of the study are threefold:

1. to investigate what children think in relation to the concept of childhood;

2. to reflect the different places children give to themselves in different international societies; and

3. to analyse how this affects children's rights and child participation.

The present article focuses on some initial findings from the first groups of children invited to engage in philosophical dialogue on the value of childhood. The children, aged between 
four and ten years live in Australia, Brazil, Bulgaria, Canada, China, England, Portugal, Scotland, South Africa, Switzerland and Vietnam. This article focuses on the first groups of children from Brazil, Bulgaria, Canada, China, Portugal, Scotland and Switzerland. The countries differ with regard to their education, cultural and political traditions, yet they have ratified the UNCRC and thus are obliged to work to promote children's voices and participation. Before presenting the findings, we first proceed to frame the concept of child and childhood theoretically and then outline methodological issues used in the study. Later, we present the children's responses, which are subsequently reflected and analysed according to the study's overall objectives regarding children's place within society, children's rights and child participation before concluding with the possible implications of our findings for children's participation.

\section{The "child" as being versus becoming, protected or liberated}

Children are human beings. And yet, children are considered different from adult human beings. The place and value of child and childhood is controversially discussed in the context of philosophy (Kennedy, 1992, 2003, 2006; Cassidy 2007, 2012; Griffiths, 2008; Stables, 2008; Kennedy \& Kohan, 2014) and sociology (Jenks, 1996; Hallett \& Prout, 2003; James \& James, 2004; Cook, 2009; Rysst, 2010; Alderson, 2013). Put in a nutshell, the discussion evolves around the question of whether children are considered as human beings, possibly of a special kind such as 'young human beings' or rather, as human beings in their becoming. The difference amounts to interpreting being a child as a state or a transitional phase on the way to becoming an adult. Depending on whether we conceive of childhood as a state in its own right and with its own value or as a transitional phase that ultimately aims at acquiring the necessary equipment that allows a child to live a successful life as an adult, 
the present child's welfare is judged differently. On one side, it is judged from the perspective of the child's present interests and on the other, from the interests of the adult the child will become (Betzler \& Bleisch, 2015: 31). There is a third point of view, and that is in relation to the interests of those making decisions about children - adults.

In the Western tradition, it was Jean-Jacques Rousseau in 1762 who advanced the notion that child is a special state, and considered a child as a being. According to him, childhood should be preserved as long as possible and that this childhood is a space of innocence and discovery. Those who conceive of childhood in these terms distance themselves from a conception that sees children as being rational, finished or having certain qualities. On the contrary, children can be seen as entities in their own right and thus any type of action on them might be seen as constraining which then requires special justification (Brennan, 2014; Gheaus, 2015). But this conception has seen its critics who suggest that conceiving of childhood as a time of innocence falls prey to a dangerous romanticism; dangerous insofar as it may be, as Cook (2009) suggests, not so much in the interests of children but those of the adults that are desperately trying to preserve their own memories of their own childhood. These treasured memories, blinded by romanticism, can easily (mis)lead one to assume that children are in need of great protection. This, of course, is not to deny that children demand protection, as articulated in the UNCRC (United Nations, 1989), but it could be argued that certain levels of protection might be used to justify isolating them from society, or diminishing their opportunities to participate more fully.

However, if we conceptualise child and childhood in terms of becoming, we find the same challenging outcome. The Aristotelian notion of potential is writ large in discussions of children as becomings, with the child being seen as unfinished and lacking in certain 
qualities, abilities or attributes (Jenks, 1996; Kennedy, 2006; Stables, 2008). In this, childhood is considered as a predicament out of which adults must lead children. Childhood is, therefore, merely a preparatory phase to adulthood, the former being instrumental regarding the values, goods and interests of the latter. And yet again, it is adults' perspectives that dominate and define the relevant goods children should achieve to the benefit, it is said, of the adult the child will become. Subsequently, it is adults again who define and shape the society to which children should aspire.

Conceiving of childhood as a state or a phase risks it being used to overpower the children's interests by those of the adults. The children, in turn, are stifled and excluded from a society formed and defined by adults' interests until they -the children - are trimmed and shaped in a way that allows adults to find children agreeable. This demonstrates the power relation between adult/child quite clearly. Issues of power and status run through discussions of children's lives with the consensus tending to suggest that children are not considered full members of society (see, for example: Kennedy, 1992, 2003, 2006; Friquenon, 1997; Qvortrup 2006, 2007; Mayall, 2007; Cassidy, 2007, 2012; Cook, 2009). Freeman (1998), for instance, talks about helicopter parents or helicopter adults more generally. Children are required to say who their friends are, what they play at, why they play in a certain way or what they think about certain things - the newly launched Barbie Doll recording all children's activity has become an emblem of this position. The child cannot be trusted to think the right things, to play with the right people or to engage with their world without supervision. Those considered to be adult are not subjected to the same levels of scrutiny or surveillance into their private realms. 
It is largely accepted that the interpretation of children's rights and children's agency in terms of participation depends on what status children have in society and whether they are approached from a paternalistic and protective perspective, or, on the contrary, from a more emancipatory and liberationist perspective (Hansen, 2012). In discussing children's status Qvortrup (1994) makes clear the lack of power children are given in society. Hammersley (2016) challenges the notion of child as different, saying that difference is emphasised when it suits adults, such as when discussing children's rights. The point at issue is that child is a social construction and this social construction is founded from an adult perspective; it is adults who have been determining child. Knowing children's views on child and childhood are crucial in determining what needs to be done to engender effective implementation of children's rights and child participation. There is little argument that children are rights holders, though there is variance in the ways in which children are able to access their rights. Increasingly, particularly since the adoption of the UNCRC, the notion of children's voices and their participation, as advocated under Article 12, has risen to the top of many countries' agendas. This study counterbalances the adult dominated perspective on child and childhood by providing insights into children's views on the two concepts as they were construed in philosophical dialogue. The philosophical dialogue allows for the reconstruction of the children's conception, or better, it offers multiple and multilateral constructs of the two concepts, because any statement made is analysed, rejected, refined and complemented by arguments and reasoning in the course of the dialogue by the children themselves.

\section{Methodology of the study}


The research methodology builds on the work of Conrad et al (2015) where Philosophy with Children was used to collect data that was subsequently analysed by the grounded-theory methodology.

\subsection{Methods of Inquiry}

The study collected data through Philosophy with Children (Murris, 2000; Lipman, 2003; García-Moriyón et al, 2005; Cassidy, 2007; Daniel, 2008; McCall, 2009; Daniel \& Auriac, 2011; Kohan, 2014). Philosophy with Children (PwC), simply put, involves children engaging in structured, philosophical discussion that is chaired or facilitated by a practitioner who has some training in PwC.

To stimulate the dialogue, all children read a short stimulus story. The story was based on one created by Brennan (2014) that raised issues around being a child/adult and the status of children/adults by addressing the question mentioned at the beginning of the article, i.e. if the children would or would not take a pill that would turn them into adults instantly. It is important to note that the story had to be adapted to take account of the cultural differences in the participating countries.

Following the reading of the stimulus and the question, the children engage in the dialogue. The facilitator is responsible for moving the dialogue forward. When the children make their contributions they agree or disagree or, indeed, agree and disagree with something that has previously been contributed and provide a reason for that dis/agreement. The dialogues belonged to the children in that the facilitators only intervened to seek clarification in the form of requesting examples or to request an explanation of a term or word being used or a point being made. The dialogues lasted between twenty-five and sixty 
minutes, depending on the time available in the classrooms rather than being determined by the age or abilities of the children involved.

The full study considers children aged around five, ten and fifteen. These age groups were chosen as they represent the approximate start, mid and end points of formal, compulsory education for the children in the study, though it is acknowledged that these vary across the countries concerned. The countries represented come as a consequence of discussions at a research conference the authors attended, thereby building on existing networks. For the present article, the authors of the study have focused on the recordings with children between the ages of four to ten as this was the first group the researchers worked with. Five groups are aged 4 to 6 (Bulgaria, China, Portugal, Scotland and Switzerland), three groups aged 6 to 7 (Brazil, Bulgaria, Canada) and two groups aged 9-10 (China, Switzerland). There was no discernible gender split, with male and female participants being equally represented. The authors of the article collected the data individually by recording the sessions and transcribing the data originating from the philosophical dialogues. Given the geographical spread and range of languages spoken, it was not possible to share the dialogues and analysis with the children.

\subsection{Methods of Analysis}

All dialogues were transcribed and then codified using Corbin and Strauss (1990) and Strauss and Corbin's (1998 \& 2010) grounded theory methodology. The analysis proceeded with open, axial and selective coding in order to identify the key codes elicited during the dialogues upon which categories and subsequently a theory, when saturation is reached, related to the concepts of child and childhood can be provided. The different types of codings and categorizations were used to reconstruct the different lines of arguments 
revolving around the concepts of child and childhood. These were thereafter reflected on a meta-theoretical level using the corresponding literature on the place of the child and childhood in philosophy, sociology and education (e.g. Stables, 2008; Cassidy, 2012; Alderson, 2013; Rysst, 2015; Kennedy \& Kohan, 2014; Wright, 2015).

It is important to acknowledge the tension between facilitating children's voices and analysing them as adults from outwith the dialogues. As far as possible, we have worked, in our analysis, to retain the integrity of the children's views and have tried not to interpret what has been said, though we have grouped and coded the content of the dialogues. All names have been changed in order to assure the children's anonymity.

\section{Findings}

As the research is still ongoing, definite conclusions cannot yet be drawn. However, the findings from the dialogues analysed so far allow us to make initial observations in relation to what children think of childhood, being a child and their place within society. This, then, enables us to reflect on children's place in society and, most notably, their participation and other associated rights, not to mention the concept of child qua child. In addition, the findings elucidate these aspects from the perspective of an age group that is most often ignored when it comes to these issues. There is no clear distinction in responses between the age groups or between boys and girls, therefore, children's ages and gender have not been recorded in the findings below.

\subsection{Themes and categories}


Across the groups there were key themes in common. Within the initial coding, the commonality stretched across codes relating to play, having friends, attending school, freedoms, money, employment and possessions. When these were further distilled, the emerging categories were: children; adults; freedom; development; family. There was little by way of difference in the categories, though the Chinese and Bulgarian children spoke about science and technology and the Brazilian, Bulgarian, Chinese and Scottish children's contributions also suggest a category that is neither child nor adult to which babies and teenagers belong.

\subsubsection{Children}

It was very clear across the countries and age groups that the participants saw child as something very different from adult. The division was clearly articulated around decisionmaking and responsibilities. Children were seen to have fun and to play with their friends while adults do not have fun. For example, as when Anna from Scotland says, 'they don't go out with their friends, the adults' or Vesko from Bulgaria who suggests that as a child 'You can play with toys and run around, and play with friends'. Her peer, Stela, though, acknowledges that 'when you grow up, you play again, but not like children', but this is in the context of playing with one's grandchildren. Rui from Portugal was clear that 'Adults do not like to play'. One of the Canadian children, Marie, proposes that children have a right to play.

One child in the study, from Brazil, is extremely clear about the status of children: 'everyone beats me; my father beats me, my mother beats me, my sister beats me... it's better to be an adult, no-one would beat me if I'm an adult'. This is the only explicit example of such 
abuse of power by adults, but it is important in contextualising some children's experiences of their childhood and their understanding of the place of children.

\subsubsection{Adults}

Adults, in contrast to children, have the responsibility to work. Virginie from Canada makes clear that this is not desirable: 'I don't want to be an adult because I would have to work and I don't want to work'. Work is clearly not seen as desirable by the majority of the children though they recognise that if one works one is able to buy things. Being able to buy things is the main reason children give for wanting to be an adult and have work, such as Tommy from Scotland who says that 'when you're an adult you get a job and make money [and] that means you could buy whatever you want; you could get a good house and a good car'. Emily from Switzerland echoes this sentiment when she suggests that 'it is important to have money: then you can buy things you otherwise couldn' $t$ '. Some children offer ideas of things they would buy such as Claude from Canada who suggests that if he was an adult he 'could buy himself a cat', or Sylvie who would buy sweets, or Paolo from Brazil who suggests that he would have 'a big house with a swimming pool and a Ferrari'. José from Portugal identifies adults' responsibilities and asserts that he does not want to be an adult because 'I don't enjoy having troubles'.

\subsubsection{Freedom}

The ability to buy things you want as a consequence of working is one manifestation of the participants' notions of adults' freedoms, though perhaps an ambiguous freedom since they are obliged to work to get what they want. The children, though, do not articulate this ambiguity so clearly. The Scottish children spoke of being able to go wherever you want as 
an adult, whenever you want, which Sylvain from Canada recognises when he says that when he is an adult he will be able to go to a bar or a restaurant as Ali from Bulgaria suggests. Thassio from Brazil wants to go further and suggests that adults have freedom to travel to 'a better place' that is less 'ugly' such as New York or Manaus.

Decision-making is aligned with the freedoms one has. While children are free to play in a way that adults no longer do, their freedoms are also limited by adult decisions. One child, though, said that 'if you go into a playground as an adult that would look strange'. Thus, adults have limited freedom, too, but limited freedom is still the predominant theme in children's lives. The Scottish children spoke at length about the quality of technology their parents allowed and did not allow them to have. The Bulgarian children, while agreeing with the limits to their freedoms by the decisions adults make for them, also proposed that they can subvert this in some way by the responses they give. Boyan exemplifies this by saying, 'If your father says to you [that] you need to have lunch very fast because we have to go somewhere else, you can say `I want to eat slowly because my tummy will get a stomach-ache'. Such instances of child decision-making were, however, very rare in the dialogue. Bernardo from Portugal makes clear that 'Adults and school tell us things we have to do; if we don't do them, then we are grounded' and Lina, from Bulgaria, articulates succinctly, in response to the suggestion that children do not decide things, 'They [adults] don't allow us'.

It should be noted that though the adults have many freedoms, they also have much responsibility and their freedoms may be curtailed by these. This is echoed by the fact that adults need to work in order to earn money to buy things. Fan from China said that sometimes adults are ordered to do things by their superiors at work and Lea from 
Switzerland suggest that 'Adults have to follow many rules'. Despite these limitations of freedom, none of the other children offered comments that positioned adults as being less than empowered in terms of their decision-making. Family responsibilities across the groups were recognised and these sometimes may limit adults' freedoms as they have to buy things such as food for the family or look after other family members. None of this, though, was considered problematic by the children. Certainly, it seems odd to suggest that the children recognise there are limitations on adults' freedoms but that they do not see this as problematic. This would be understandable if children think that everyone is told what to do because this is their existence. What is important is that even if adults are told what to do, it is other adults doing the ordering and supervising; children are never in the dominant position. Adult power is retained.

\subsubsection{Family}

Indeed, the children from Brazil, Bulgaria, Canada, China, Portugal and Scotland recognised the place of family in their lives. They saw themselves as members of the family but not as individuals who had any power in the family. In the Chinese group, Ping spoke about being 'powerless' to intervene when she sees her parents quarrel with one another.

Many children situated themselves against what they were permitted as opposed to their older or younger siblings. Even the notion of co-operation in the family context, as outlined by the Brazilian children, seems to be dictated by adults. Parents do housework, as suggested by the Scottish children, while they do their homework, thus defining the children's realm. Angus suggests that parents help with their children with their homework, while Afonso talks about helping his mother with housework. Hongyu from China also suggests that homework is in the children's realm but that this is situated in the family 
context. Adults, in all the dialogues, take care of the family; the place of the children is to be cared for. In the Chinese group, Ping says that 'When I'm a kid my parents take me outside to play and travel, and when I'm an adult, I would take them outside to play and travel' - referring to her own children by 'them'.

\subsubsection{Development}

The reason children saw themselves as being cared for in the family and by schools linked to their development. This may be related to them being younger or smaller and the need to grow bigger or taller to be an adult. Very often the children spoke about their intellectual development. All the groups spoke about going to school or learning. This need of learning was sometimes in order that one would be qualified in order to acquire a job or to be 'smarter' because adults are seen to know things, or, as Teresa from Portugal suggested, so that they do not grow up to be 'ignorant adults'. The Swiss children spoke about needing to learn things as children because that place is no longer available when one's childhood is over. Learning appears to be the exclusive privilege of children.

Just as the child is seen as developing, the adult is seen as diminishing in some sense. Ping, above, talks about caring for her parents as they age and Jamal from Scotland poses that adults start to lose their memories and children have to help them to remember things. Jean from Canada says that he does not want to be an adult because 'when we get older we die', a feature also noted by the Bulgarian and Portuguese children.

For some groups there was a further distinction to be made. The Canadian children spoke about teenagers as being different from adults and to children; teenagers 'can do things that are cool'. Similarly, the children in Scotland also identified teenagers as being different 
with Jenny suggesting that they might have responsibility for baby-sitting and Tomas from Brazil introducing the word 'adolescent'. Further, babies are also seen to be different by this group because they don't know how to do things that older children might, such as using technology in the form of mobile phones. Luc from Canada suggested that there are two stages to life and that both have advantages and disadvantages but he said he favoured the compromise of being a teenager.

\subsection{The importance of childhood}

The children talked about 'growing-up'. Childhood was seen as a transient period in one's life and that everyone ought to go through this. There was, for some children, no point in taking the pill to become an adult because being a child is an important part of one's life. Ying from China expresses the view held by other groups eloquently when she says that 'Growing-up is like reading a book. You should read the book page by page; if you read the end of the book directly it would be meaningless'.

The Bulgarian groups spoke about the nostalgia that adults have of childhood and the need they, adults, therefore, have to cherish it. Christian from Switzerland pointed out that in taking the pill the child in the story would lose all the potential memories from childhood and that this was not positive for the adult. Tao from China also recognised this, saying that it would be a lonely experience because 'When you become a grandparent, you couldn't tell your grandson or granddaughter the story of your childhood'. In the same way, Yanwen from China said that 'Childhood is a special period of a person's life... Even if there is a happy and sad time, both of them would become a precious memory when he or she grows up' or Mao who said that 'you would miss many precious things, including your mother's love'. The Swiss children saw experiencing childhood as important with Elena noting that if the child in 
the story had taken the pill 'she would have lost her childhood and there is nothing nicer than childhood'.

Some issues arose around whether or not individuals could immediately grow taller or if they were recognised by others, the focus was rather on the consequences of taking the pill. The Chinese children suggested that the person would be a 'false adult' who 'doesn't have enough knowledge and ability to find a good job... and who would not be trusted'. This type of adult, thought the Swiss children, would not understand the world and possibly still feel like a child despite being an adult. Liang suggested that 'Since the pill could change a person to an adult from a child, then we are sure to invent another kind of pill to change a person from an older man to a child', and this would be desirable 'If I find it's not happy to be an adult, I would eat the pill to change into a child again'.

\section{Discussion}

This final example from Liang suggests that even in the event of becoming an adult, child is still more desirable. What is interesting that the children, in talking about the thought experiment they have been given, articulate across all the groups both the intrinsic and instrumental goods of childhood.

\subsection{Children's place in society}

The language of 'becoming', such as that articulated by Qvortrup (1994), Jenks (1996), Kennedy (2006) and Stables (2008) is evident throughout the dialogues. The children see the instrumental value of childhood as being a place where they are prepared, where they learn in order to be able to participate more fully later in their lives. This participatory freedom will revolve around the world of work, of making money, of caring for one's family 
and of making decisions. Childhood, under this view, is very much a phase to be gone through in order to be smarter, to gain the knowledge and skills that allow one to adopt the mantle of adult. This said, though, it is also an enjoyable phase, one where one has limited responsibilities and life is more fun. It is interesting that the children limit adults' participation also, though this is understandable. If they have only limited reference to the adult world, then they will not be able to see what freedoms may be on offer.

The intrinsic value of childhood is, however, also appreciated. The children were clear that one shouldn't be deprived of one's childhood. While it is a phase of preparation, in and of itself it is a good thing. It is, as Kohan (2011) suggests 'a revolutionary space of transformation' (p.342), but for many, the talk is of losing one's childhood, which is not desirable. Childhood is a time that ought to be protected. The children, in holding this view, very much echo the sentiments of Rousseau $(1762 / 1948)$ and the romantic view of childhood as a time of innocence that should be prolonged and enjoyed. Despite highlighting the intrinsic value of childhood, none of the children saw themselves as in positions where they might engage beyond the family, friends and play. They did not see themselves as participatory beyond 'their world' and the goods of childhood seem to be ineffective unless they are recovered by the adults' cherished memories, as Cook (2009), above, suggests. While this view of the child might be beneficent in intention, it highlights children's lack of status and impact. Indeed, beyond the world of work, the notion of wider society was not mentioned by the children at all.

\subsection{Children's participation}

The only instances of the children speaking directly about their actions being limited came in the Brazilian and Bulgarian groups when the children said that they had to follow orders 
because adults do not allow them to make decisions. It could be argued that children perceive of adults as being the ones who point out the limits of the children's world and give care to children, both aspects indicate a protective stance towards children. Of course, adults work to protect children but given the dilemma outlined above, it is this protective stance, predominant in Western society (Stoecklin, 2013), that risks posing something of a threat for children in terms of their opportunities for participation. At this stage of our research, the dilemma presents itself related to the adults' power to negate children's participation in the family and to indicate to them the limits and borders of their world at different moments in their life. Under such a regime, children will not be able to see themselves as part of wider society, a society that ultimately reflects adults' needs and interests. In order to overcome this dilemma it seems necessary to abandon the protective stance on children and approach them from an emancipatory and liberationist view. This is not, of course, to deny children their right to protection or provision as outlined in the UNCRC. Very clearly, they are not in positions that allow them to protect themselves from certain ills or to provide for themselves. The protective stance that is problematic in this context is the one that limits children's participation in decision-making and other forms of social and political activity. It is worth noting, though, that they do not speak much about adults' participation in society in the wider political sense. They accept, wittingly or otherwise, that adults have control and that they - children - can do little to alter the situation. It is stronger than this; in some cases they seem not to be aware that they might participate and contribute more fully than at present. This can only limit children's status.

The children see clearly a distinction between the world of the child and that of adults. While they recognise theirs as a world with more fun, they do not conceive of it as having an 
impact on the lives of adults. Seeing children as 'other' or, indeed, seeing adult as 'other' is not helpful. Children will always under this view, be seen as deficient in some way and, as such, they will not be positioned, or even think to position themselves, as anything other than lower in status than adults. Children, though, are never likely to want to reposition themselves, or allow themselves to be repositioned, if the prevailing view is one that sees adulthood as not worth having. The children in this study acknowledge that adults make decisions, that they buy things and have certain freedoms not accessible to children. However, these freedoms, whether in being able to do as one chooses or to buy things or to make decisions, come at a cost; adult life is not fun. It would be easy to underestimate how important such a sense is. Fun is often portrayed as superficial, irresponsible, immature and not for adults who have the serious business of life to lead. In establishing and perpetuating the notion that adulthood is undesirable, children will not wish or try to participate, their status is maintained. This allows adults to ensure their interests dominate and that children stay within the realm of preparation where they learn what it is to be a participant in the wider (adult) world.

\section{Conclusion}

This study uniquely involves children from around the world in addressing the question of what it is to be a child. Matthews (1994) notes that the nature of childhood might go unquestioned and that the notion of child/childhood may even go unexplored. Later, he (Matthews \& Mullin, 2015) notes that in asking questions about childhood, it is important to come to some understanding of how childhood is conceived. The project presented here acknowledges the importance of seeing how childhood is conceived but, more specifically, 
recognises that it is indispensable to know the opinions of those conceived, i.e. the children themselves.

It was clear from all the dialogues in the present study that adults and children are seen by the children to be different. This is not a comment on how children broadly are treated in the individual countries involved in the project, but how the children in the study perceive themselves in relation to adults, thereby illustrating the lived experiences of the children concerned. The implication of this is that while there may be legislation within countries in relation to children and their rights, this is undermined by the adult/child divide that, according to the children in this study, persists. This, therefore, has implications for children's rights in relation to their position in society.

While adulthood affords certain levels of freedom in relation to choices and decisionmaking, childhood is seen to be the more desirable state. This is important in taking forward the agenda around children's participation rights. The very fact that adulthood is portrayed and perceived as being undesirable means that children may not take opportunities or try to gain access to their participation rights, and this is a constraining force. Adulthood is so unappealing because it is devoid of fun and friendship and is dominated by responsibility and the need to be 'grown-up'. Of course, having a life of fun and learning is desirable, but this is true for all, not just for the younger members of our society. Having the opportunity to make decisions that affect one's life, though, also has the potential to make life more enjoyable and fulfilling.

What the findings so far suggest is that if we are to be serious about ensuring children's participation then the politics of difference must be challenged and a new way of seeing and speaking about being child/adult ought to be encouraged. The positive view of childhood 
children provide surely provides a good starting point in order to proceed and support them to see themselves as holding an important part in wider society.

\section{References}

Alanen, L., "Disciplinarity, Interdisciplinarity and Childhood Studies", Childhood 2012 (19(4)), 419-422. DOI: 10.1177/0907568212461592.

Alderson, P., Childhoods Real and Imagined. (Abingdon, Oxon.: Routledge, 2013).

Betzler, M. and Bleisch, B., "Familiäre Pflichten in Kontext der Familienethik. Einleitung”, in M. Betzler and B. Bleisch (eds.), Familiäre Pflichten (Frankfurt am Main: Suhrkamp, 2015).

Brennan, S., "The Goods of Childhood and Children's Rights", in F. Baylis and C. Mcleod (eds.), Family-Making: Contemporary Ethical Challenges (Oxford: Oxford University Press, 2014).

Cassidy, C. Thinking Children. (London: Continuum, 2007).

Cassidy, C., “Children's Status, Children's Rights and 'Dealing With' Children”, International Journal of Children's Rights 2012 (20(1)), 57-71. DOI: 10.1163/157181812X608282.

Conrad, S-J., Cassidy, C. and Mathis, C., "Encouraging and Supporting Children's Voices”, in J. Tremmel, A. Mason, I. Dimitrijoski and P. Godli (eds.), Youth Quotas and Other Efficient Forms of Youth Participation in Ageing Democracies (Cham: Springer, 2015).

Cook, D.T., "Editorial: When a Child is Not a Child, and Other Conceptual Hazards of Childhood Studies", Childhood 2009 (16(1)), 5-10. DOI: 10.1177/0907568208101687. 
Corbin, J. and Strauss, A., "Grounded Theory Research: Procedures, Canons, and Evaluative Criteria", Qualitative Sociology 1990 (13(1)), 3-21. DOI: 10.1007/BF00988593.

Daniel, M-F., "Learning to Philosophize: Positive Impacts and Conditions for Implementation. A Synthesis of 10 Years of Research (1995-2005)", Thinking 2008 (18(4)), 36-48.

Daniel, M-F. and Auriac, E., "Philosophy, Critical Thinking and Philosophy for Children", Educational Philosophy and Theory 2011 (43(5)), 415-435. DOI: 10.1111/j.14695812.2008.00483.x.

Freeman, M., "The Sociology of Childhood and Children's Rights", International Journal of Children's Rights 1998 (6(4)), 433-444. DOI: 10.1163/15718189820494175.

Friquenon, M-L., "What is a Child?", Thinking: the Journal of Philosophy for Children 1997 (13 (1)), 12-16.

García-Moriyón, F., Rebello, I. and Colom, R., “Evaluating Philosophy for Children: a Meta Analysis", Thinking 2005 (17(4)), 14-22.

Gheaus, A., "The 'Intrinsic Goods of Childhood' and the Just Society", in A. Baggatini and C. Macleod (eds.), The Nature of Children's Well-Being. (Cham: Springer, 2015).

Griffiths, M. (2008) Research for Social Justice: Empowerment and Voice. Paper presented to the Joint Glasgow/Strathclyde Research Group on Teacher Education and Teachers' Work Seminar, 13 May 2008, University of Glasgow.

Hallett, C. and Prout, A. (eds.), Hearing the Voices of Children. (Abingdon, Oxon: Routledge Falmer, 2003). 
Hammersley, M., “Childhood Studies: a Sustainable Paradigm?”, Childhood 2016 Online first: DOI : 10.11177/0907568216631399.

Hansen, K., "Schools of Thought in Children's Rights", in M. Liebel (ed.), Children's Rights from Below: Cross-Cultural Perspectives. (Bastingstoke: Palgrave Macmillan, 2012).

James, A. and James, A., Constructing Childhood: Theory, Policy and Social Practice. (New York: Palgrave Macmillan, 2004).

Jenks, C., Childhood. (London: Routledge, 1996).

Kennedy, D., "The Hermeneutics of Childhood", Philosophy Today Spring 1992, 44-58.

Kennedy, D., "The Child and Postmodern Subjectivity”, Educational Theory 2003 (52(2)), 155-167. DOI: 10.1111/j.1741-5446.2002.00155.x.

Kennedy, D., The Well of Being. Childhood, Subjectivity, and Education. (Albany: SUNY Press, 2006).

Kennedy, D. and Kohan W.O., "School and the Future of Scholé: a Preliminary Dialogue", Childhood \& Philosophy 2014 (10(19)), 199-216.

Kohan, W.O., "Childhood, Education and Philosophy: Notes on Deterritorialisation”, Journal of Philosophy of Education 2011 (45(2)), 339-357. DOI: 10.1111/j.1467-9752.2011.00796.x.

Kohan, W.O., Philosophy and Childhood: Critical Perspectives and Affirmative Practices. (New York: Palgrave Macmillan, 2014).

Lipman, M., Thinking in Education. (Cambridge, Mass.: Cambridge University Press, 2003). 
McCall, C., Transforming Thinking. Philosophical Inquiry in the Primary and Secondary

Classroom. (London: Routledge, 2009).

Matthews, G.B., The Philosophy of Childhood. (Cambridge: Massachusetts: Harvard University Press, 1994).

Matthews, G. and Mullin, A. (2015). The Philosophy of Childhood. In E. N. Zalta (ed.)The Stanford Encyclopedia of Philosophy (Spring 2015 Edition).

<http://plato.stanford.edu/archives/spr2015/entries/childhood/>.

Mayall, B., "The Sociology of Childhood in Relation to Children's Rights", International Journal of Children's Rights 2007 (8(3)), 243-259. DOI: 10.1163/15718180020494640.

Murris, K., "Can Children do Philosophy?", Journal of Philosophy of Education 2000 (34(2)), 261-279. DOI: 10.1111/1467-9752.00172.

Qvortrup, J., “Editorial: Are Children Subjects or a Liability?”, Childhood 2006 (13(4)), 435439. DOI: $10.1177 / 0907568206068555$.

Qvortrup, J., “Editorial: A Reminder.” Childhood 2007 (14(4)), 395-400. DOI: $10.1177 / 0907568207081957$.

Qvortrup, J., Bardy, M. Sgritta, G. and Wintersberger, H. (eds.), Childhood Matters; Social Theory, Practice and Politics. (Aldershot: Avebury, 1994).

Rousseau, J.-J., Èmile or Education. (London: J.M. Dent and Sons Limited, 1948).

Rysst, M., "II am Only Ten Years Old': Femininities, Clothing-fashion Codes and the Intergenerational Gap of Interpretation of Young Girls' Clothes", Childhood 2010 (17(1)), 7693. DOI: $10.1177 / 0907568209351552$. 
Rysst, M., "Friendship and Gender Identity Among Girls in a Multicultural Setting in Oslo", Childhood 2015 (22(4)), 490-505. DOI: 10.1177/0907568214549081.

Stables, A., Childhood and the Philosophy of Education. An Anti-Aristotelian Perspective. (London: Continuum, 2008).

Stoecklin, D., "Theories of Action in the Field of Child Participation. In Search of Explicit Frameworks", Childhood 2013 (20(4)), 443-457. DOI: 10.1177/0907568212466901.

Strauss, A. and Corbin, J., Basics of Qualitative Research Techniques and Procedures for Developing Grounded Theory (2nd edition). (London: Sage, 1998/2010).

Turner, S.M. and Matthews, G.B. (eds.), The Philosopher's Child. Critical Essays in the Western Tradition. (Rochester, NY: University of Rochester Press, 1998).

United Nations, United Nations Convention on the Rights of the Child. (Geneva: United Nations, 1989).

Wright, H.R., The Child in Society. (London: Sage, 2015). 